\title{
Impact of increasing Antarctic ice-shelf melting on Southern Ocean hydrography
}

\author{
Caixin WANG, ${ }^{1,2}$ Keguang WANG ${ }^{3}$ \\ ${ }^{1}$ Department of Physics, University of Helsinki, Helsinki, Finland \\ E-mail: caixin.wang@npolar.no \\ ${ }^{2}$ Norwegian Polar Institute, Tromsø, Norway \\ ${ }^{3}$ Norwegian Meteorological Institute, Tromsø, Norway
}

\begin{abstract}
Southern Ocean hydrography has undergone substantial changes in recent decades, concurrent with an increase in the rate of Antarctic ice-shelf melting (AISM). We investigate the impact of increasing AISM on hydrography through a twin numerical experiment, with and without AISM, using a global coupled sea-ice/ocean climate model. The difference between these simulations gives a qualitative understanding of the impact of increasing AISM on hydrography. It is found that increasing AISM tends to freshen the surface water, warm the intermediate and deep waters, and freshen and warm the bottom water in the Southern Ocean. Such effects are consistent with the recent observed trends, suggesting that increasing AISM is likely a significant contributor to the changes in the Southern Ocean. Our analyses indicate potential positive feedback between hydrography and AISM that would amplify the effect on both Southern Ocean hydrography and Antarctic ice-shelf loss caused by external factors such as changing Southern Hemisphere winds.
\end{abstract}

\section{INTRODUCTION}

The Southern Ocean has undergone significant changes in recent decades (see review by Jacobs, 2006): for example, rising temperature in the upper $3000 \mathrm{~m}$ (Levitus and others, 2000, 2005; Gille, 2002, 2003), and decreasing salinity in high-latitude waters (Jacobs and others, 2002; Whitworth, 2002; Boyer and others, 2005). These changes have been interpreted as being a result of natural variability, anthropogenic effects or both (Levitus and others, 2000). The surface freshening in the Ross Sea has also been linked to the increased precipitation, reduced sea-ice production and increased melting of the West Antarctic ice sheet (Jacobs and others, 2002).

In recent decades, Antarctic ice-shelf melting (AISM) has also been observed to be increasing, especially in the Amundsen and Bellingshausen Seas (Shepherd and others, 2004; Holland and others, 2010; Jacobs and others, 2011; Pritchard and others, 2012). Such increases have been attributed mainly to oceanic forcing (Shepherd and others, 2004; Walker and others, 2007; Thoma and others, 2008; Wåhlin and others, 2010).

While the interactions between the Southern Ocean and the Antarctic ice shelves are complex, our focus in this study is to investigate the impact of increasing AISM on Southern Ocean hydrography.

\section{METHOD}

The ORCA2-LIM model used in this study is a global coupled sea-ice/ocean model (Timmermann and others, 2005). It consists of an ocean model, ORCA, based on a global configuration of OPA (Ocean PArallelise), which is a free sea surface, primitive-equations ocean model (Madec and others, 1998; http://www.lodyc.jussieu.fr/opa/), and a dynamic-thermodynamic sea-ice model, LIM (Louvainla-Neuve sea-Ice Model; Fichefet and Morales Maqueda, 1997), which employs a viscous-plastic rheology for sea-ice dynamics following Hibler (1979) and a three-layer snow/ ice thermodynamic model following Semtner (1976). The model has a mean resolution of $2^{\circ}$ in the horizontal, and 31 vertical layers in the ocean model with grid spacing from $10 \mathrm{~m}$ in the top $100 \mathrm{~m}$ to $500 \mathrm{~m}$ at the bottom, and 1 (for dynamics) or 3 (for thermodynamics) vertical layers in the sea-ice model. Its model domain extends to about $78^{\circ} \mathrm{S}$ in the south, not including any of the Antarctic ice shelves (Wang, 2011).

Antarctic ice shelves fringe nearly half of the Antarctic coastline (Drewry, 1983). Ice-shelf melting (ISM) takes place at the base of these shelves (Jacobs and others, 1992). The thermodynamic interaction between ice shelf and ocean has been parameterized by Beckmann and Goosse (2003). They assumed that the net heat, $Q_{\text {net, }}$ and freshwater flux, $m_{\text {net, }}$ are proportional to the difference between the oceanic temperature outside the cavity, $T_{\text {ocean, }}$ and in situ freezingpoint temperature at the base of the ice shelf, $T_{\mathrm{f}}$, and an effective area of interaction, $A_{\text {eff }}$ :

$$
\begin{gathered}
Q_{\text {net }}=\rho_{\mathrm{w}} c_{\mathrm{pw}} \gamma_{\mathrm{T}}\left(T_{\text {ocean }}-T_{\mathrm{f}}\right) A_{\text {eff }} \\
\frac{\partial m_{\text {net }}}{\partial t}=\frac{Q_{\text {net }}}{\rho_{\text {is }} L_{\text {is }}}
\end{gathered}
$$

where $\rho_{\mathrm{w}}$ and $\rho_{\text {is }}$ are the densities of sea water and ice shelf, $c_{\mathrm{pw}}$ is the specific heat, $\gamma_{\mathrm{T}}\left(=10^{-4} \mathrm{~m} \mathrm{~s}^{-1}\right)$ is the transfer coefficient and $L_{\text {is }}$ is the latent heat of fusion of the ice shelf. The ISM parameterization scheme of Beckmann and Goosse (2003) has been employed in the ORCA2-LIM model by Wang and Beckmann (2007) through modification of lateral boundary conditions where the Antarctic ice shelves are located (Fig. 1). Wang and Beckmann (2007) showed that the results with the parameterization are comparable to those from regional models with sub-ice-shelf cavities explicitly included.

Two experiments, one with and the other without AISM, were run for two passes forced with the same CORE (Coordinated Ocean-ice Reference Experiments) forcing data for 1958-2000. Using the same 43 year forcing data, 


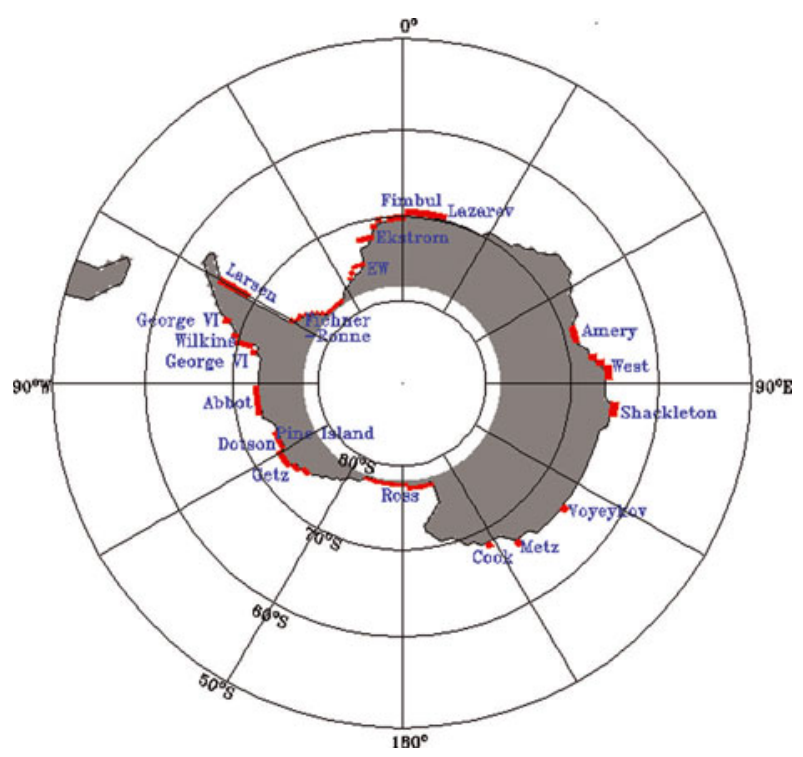

Fig. 1. The name, extent and position of the Antarctic ice shelves included in the ORCA2-LIM-ISP model. EW: Riiser-Larsen and Brunt Ice Shelves.

the first pass was set to spin up the model state, and the second was for analysis. Wang and Beckmann (2007) had reported changes in temperature and salinity at $216 \mathrm{~m}$ depth after inclusion of AISM. In this study, we further analyze these twin experiments by looking at hydrographic variability at different depths.

The simulated total annual mean circumpolar freshwater flux from AISM (Fig. 2) is $\sim 106 \mathrm{mSv}\left(1 \mathrm{mSv}=10^{3} \mathrm{~m}^{3} \mathrm{~s}^{-1}\right)$ in this study, with a range from $\sim 102 \mathrm{mSv}$ in the mid-1960s to $\sim 112 \mathrm{mSv}$ in the 1980s and 1990s (a total range of $\sim 10 \%$ of the mean). These values are a factor of 3-4 higher than previous estimates (26-32 mSv; see Section 3.1). Our two simulations, with zero AISM and mean AISM of $\sim 106 \mathrm{mSv}$, therefore represent at least an order of magnitude more variability than in the actual record of AISM. Since we do not expect Southern Ocean hydrography to respond linearly to changes in AISM over such a broad range, the sensitivity to AISM estimated from these runs is only a qualitative guide to true sensitivity over realistic ranges of variability. Nevertheless, the comparison provides valuable qualitative information on how the Southern Ocean responds to changing AISM, and the model trends can be compared with observations during the last four decades.

\section{RESULTS}

\subsection{Freshwater flux from AISM}

It is difficult to estimate the circumpolar freshwater flux from AISM. Our knowledge of the melt rate of ice shelves is mostly from estimations based on glaciological and oceanographic observations or numerical simulations, since direct measurements are still very limited due to difficulties in accessing the sub-ice-shelf cavity. However, measurements or numerical simulations have not been done for all Antarctic ice shelves. Different approaches may yield large differences in estimated ISM (e.g. due to the assumption of a steady-state ice sheet (Shepherd and others, 2004) and the selection of outflow depth (Payne and others, 2007)).

The simulated total annual mean circumpolar freshwater flux from AISM, $106 \mathrm{mSv}$, is considerably larger than previous estimates (e.g. $26.14 \mathrm{mSv}$ (Jacobs and others, 1996), $31.6 \mathrm{mSv}$ (Beckmann and others, 1999) and $28.42 \mathrm{mSv}$ (Hellmer, 2004)). However, closer inspection of the individual ISM values reveals that many of these estimates are comparable to other studies, particularly for the major ice shelves (Table 1). For example, the freshwater flux from the Filchner-Ronne Ice Shelf (FRIS) is $6.52 \mathrm{mSv}$ in this study, in good agreement with an earlier glaciological shelf-wide estimate (Jacobs and others, 1996) and the numerical results from cavity-resolving models (e.g. Timmermann and others, 2002). The freshwater fluxes from the other large ice shelves (e.g. Ross $(8.36 \mathrm{mSv})$ and Amery $(5.44 \mathrm{mSv})$, as well as eastern Weddell $(4.89 \mathrm{mSv}))$ in this study are also comparable

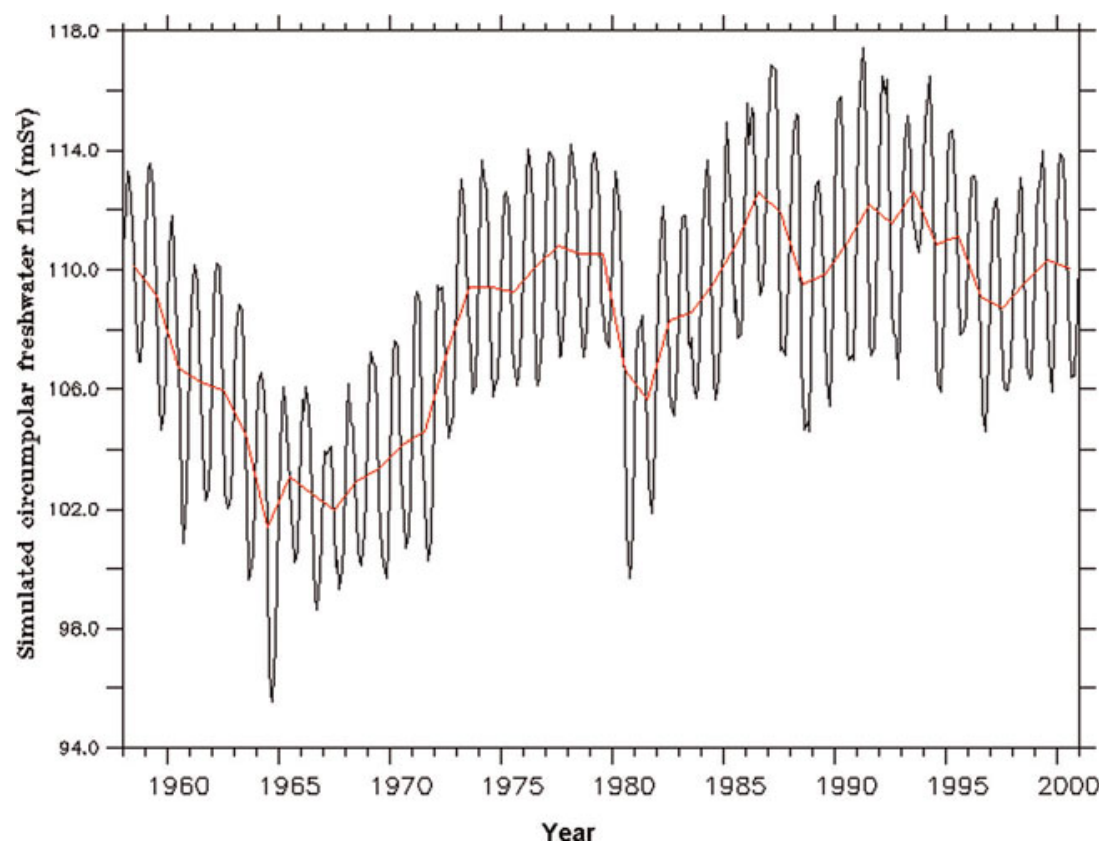

Fig. 2. Time series of the simulated monthly (black) and annual (red) mean of the total circumpolar freshwater flux from AISM. 
Table 1. Freshwater flux (mSv) from ISM in different studies

\begin{tabular}{|c|c|c|c|c|c|c|c|c|c|c|c|c|c|}
\hline \multirow[t]{2}{*}{ Ice shelf } & \multicolumn{4}{|c|}{ Observations } & \multicolumn{5}{|c|}{ Model estimates } & \multirow[b]{2}{*}{$\begin{array}{l}\text { This } \\
\text { study }\end{array}$} & \multirow[b]{2}{*}{ TH06 } & \multirow[b]{2}{*}{ P07 } & \multirow[b]{2}{*}{ JJ08 } \\
\hline & J92 & J96 & R98 & S04 & B99 & ВТ01 & T02 & BG03 & $\mathrm{H} 04$ & & & & \\
\hline Filchner-Ronne & 6.99 & 6.99 & & & 3.75 & 5.8 & 5.75 & 3.75 & 3.73 & 6.52 & & & \\
\hline Ross & 1.94 & 2.8 & & & 7.76 & 5.0 & 4.97 & 7.76 & 5.61 & 8.36 & & & \\
\hline Amery & 0.57 & 0.57 & & & 5.71 & 4.9 & 4.89 & 5.71 & 0.55 & 5.44 & & & \\
\hline George VI & 1.69 & 1.52 & & & & & & & 0.69 & 5.35 & & & $5.4-9.0$ \\
\hline Pine Island & & 0.97 & $2.28 \pm 0.38$ & $1.42 \pm 0.19$ & & & & & & 1.62 & & 1.96 & \\
\hline $\mathrm{EW}^{*}$ & & & & & 4.40 & 4.0 & 3.95 & 4.40 & 5.19 & 4.89 & 2.1 & & \\
\hline Ekström & & & & & 701 & 84 & 828 & 701 & 776 & 2.44 & & & \\
\hline Fimbul & & & & & 7.91 & 0.4 & 0.30 & 1.91 & 1.70 & 19.80 & & & \\
\hline West & & & & & & & & & & 4.54 & & & \\
\hline Shackleton & & & & & & & & & 1.47 & 8.56 & & & \\
\hline Lazarev & & & & & & & & & & 3.69 & & & \\
\hline Cook & Un- & & & & & & & & & 1.84 & & & \\
\hline Getz & differentiated & $\begin{array}{l}\text { Un- } \\
\text { differentiated }\end{array}$ & & 7.02 & & & & & 1.66 & 16.36 & & & \\
\hline Wilkins & ice shelves & difterentrated & & & & & & & & 6.67 & & & \\
\hline Abbot & & rce snetves & & 4.1 & & & & & 0.57 & 1.49 & & & \\
\hline Dotson & & & & 0.88 & & & & & & 1.62 & & & \\
\hline Larsen & & & & & 2.07 & 1.5 & 1.49 & & 1.19 & 6.33 & & & \\
\hline Total & 18.8 & 26.1 & & & 31.6 & 29.6 & 29.43 & 29.53 & 28.42 & 106.46 & & & \\
\hline
\end{tabular}

Note: J92: Jacobs and others (1992); J96: Jacobs and others (1996); R98: Rignot (1998); S04: Shepherd and others (2004); B99: Beckmann and others (1999); BT01: Beckmann and Timmermann (2001); T02: Timmermann and others (2002); BG03: Beckmann and Goosse (2003); H04: Hellmer (2004); TH06: Thoma and others (2006); P07: Payne and others (2007); JJ08: Jenkins and Jacobs (2008).

*Riiser-Larsen and Brunt Ice Shelves.

to the other studies from regional cavity-resolving models (e.g. Beckmann and others, 1999; Timmermann and others, 2002; Hellmer, 2004). The freshwater flux from the Fimbul Ice Shelf is $\sim 19.80 \mathrm{mSv}$ in this study, overestimated by about a factor of two compared with other studies (e.g. Beckmann and others, 1999; Beckmann and Timmermann, 2001; Timmermann and others, 2002; Hellmer, 2004; Walkden and others, 2009), due to the warm bias in our simulation because of the coarse model resolution (Wang, 2011). Recent in situ observations indicate that the water temperature under the Fimbul Ice Shelf is generally $<0.1^{\circ} \mathrm{C}$ above the surface freezing point (Hattermann and others, 2012), suggesting that basal melting here cannot simply be parameterized by coastal deep ocean temperatures. The modeled freshwater flux from the Getz Ice Shelf ( $16.4 \mathrm{mSv}$ ) is more than twice that estimated from glaciological measurements (Shepherd and others, 2004). The reason for this discrepancy requires further investigation. The high melt rate in the Amundsen and Bellingshausen Seas is generally consistent with available estimates. For example, the freshwater flux from the George VI Ice Shelf is $5.35 \mathrm{mSv}$ in this study, corresponding to a melt rate of $3 \mathrm{ma}^{-1}$, which is close to recent measurements of 3-5 $\mathrm{m} \mathrm{a}^{-1}$ (Jenkins and Jacobs, 2008) and $2.49 \mathrm{~m} \mathrm{a}^{-1}$ (Holland and others, 2010), although higher than previous estimates of $1.9 \mathrm{~m} \mathrm{a}^{-1}$ (Jacobs and others, 1996) and $0.43 \mathrm{~m} \mathrm{a}^{-1}$ (Hellmer, 2004). Pine Island Glacier Ice Shelf (PIG) is experiencing extremely high melt rate due to the warm circumpolar deep water (CDW) flowing onto the continental shelf. Estimates of melt rates for PIG are in a wide range, from $10 \mathrm{~m} \mathrm{a}^{-1}$ (Jacobs and others, 1996) to $24 \pm 4 \mathrm{~m} \mathrm{a}^{-1}$ (Rignot, 1998). The freshwater flux from our simulation is $1.62 \mathrm{mSv}$, corresponding to a melt rate of $21 \mathrm{~m} \mathrm{a}^{-1}$, close to the simulation of $20.6 \mathrm{~m} \mathrm{a}^{-1}$ by Payne and others (2007) with a plume model, and approximating the simulation of $28 \mathrm{~m} \mathrm{a}^{-1}$ using NASA
IceBridge data by Schodlok and others (2012). The freshwater fluxes from the minor ice shelves (Lazarev, Voyeykov, Cook and Dotson) need further verification, since there have been very few studies of these ice shelves.

The modeled total circumpolar freshwater flux from the AISM during the integration period 1958-2000 (Fig. 2) shows significant interannual variability, with a clear increase since the mid-1960s, consistent with the observed increase in basal melting during recent decades (Rignot and Jacobs, 2002; Shepherd and others, 2004). An increase in basal melting has been suggested to be a major cause of the thinning of ice shelves in the Amundsen Sea (Shepherd and others, 2004), owing to the ocean warming (Shepherd and others, 2004) and changes in wind patterns in the Southern Hemisphere (Pritchard and others, 2012; Steig and others, 2012).

\subsection{Impact of AISM on temperature}

Figure 3 shows climatological mean temperature differences $\Delta T$ (with minus without AISM) at different depths. The impact of including AISM in temperature is very complex. Water in the vicinity of the Antarctic ice shelves generally becomes colder above $216 \mathrm{~m}$ (Fig. 3a-c), due to the cold fresh water from ISM (Hellmer, 2004; Wang and Beckmann, 2007). The largest cooling is found at $216 \mathrm{~m}$ (Fig. 3c), the base of most ice shelves' edges in the model (except the FRIS and the Ross Ice Shelf (RIS)), where the heat and freshwater fluxes due to AISM are applied. Substantial cooling at $216 \mathrm{~m}$ is found in the coastal areas of the Amundsen, Weddell and Ross seas, with the most extreme values of $\Delta T$ in each region being about $-2.2^{\circ} \mathrm{C},-1.5^{\circ} \mathrm{C}$ and $-1.25^{\circ} \mathrm{C}$, respectively. The ISM of the smaller ice shelves in East Antarctica tends to cause much smaller $\Delta T$ in the vicinity of the continent, generally $<0.2^{\circ} \mathrm{C}$; the exception is the region around Amery Ice Shelf. 

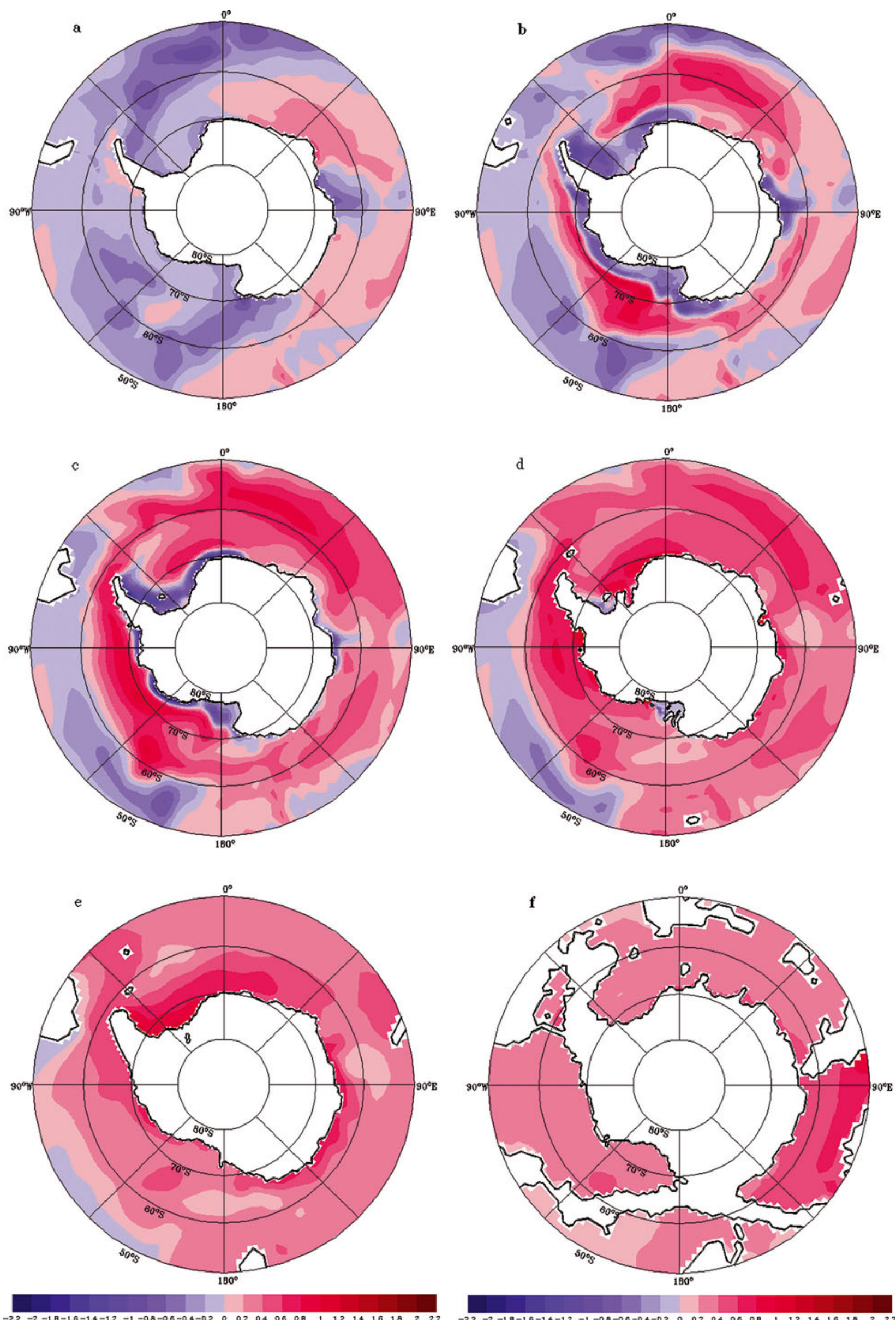

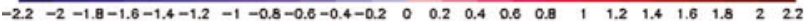

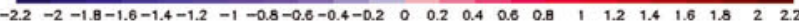

Fig. 3. Climatology mean temperature differences $\Delta T\left({ }^{\circ} \mathrm{C}\right.$; with minus without AISM) at depths of (a) $5 \mathrm{~m}$, (b) $55 \mathrm{~m},($ c) $216 \mathrm{~m}$, (d) $512 \mathrm{~m}$, (e) $1033 \mathrm{~m}$ and (f) $3752 \mathrm{~m}$. Positive temperature differences represent temperature increase (shaded red); negative temperature differences indicate temperature decrease (shaded blue). 
The coastal cooling at $512 \mathrm{~m}$ (Fig. 3d) is weak, only occurring near the much thicker ice shelves FRIS and RIS. Close to the surface, cooling affects a much larger area (Fig. 3a and b). At $55 \mathrm{~m}$ (Fig. 3b), the cooling becomes weaker but broader next to the continent, as a result of the rising cold buoyancy fresh water from the ice shelves and offshore advection by mean wind stress. At the surface (Fig. 3a), $\Delta T$ is smaller than at mid-depths, implying a more extensive mixing between the colder ice-shelf water and the warmer CDW, and a fast exchange with the atmosphere. The most pronounced cooling at the surface is not next to the continent, but in the Antarctic Circumpolar Current (ACC) region north of the Weddell Sea (down to $-1.0^{\circ} \mathrm{C}$ ). The surface cooling next to the continent is mostly $<0.4^{\circ} \mathrm{C}$ except in two regions: one is outside the Amery Ice Shelf, and the other is close to Cape Adare in the western Ross Sea, both being about $-0.8^{\circ} \mathrm{C}$.

Most of the Southern Ocean is undergoing significant warming when AISM is included (Fig. 3). Above $1000 \mathrm{~m}, \Delta T$ is generally not $>1.0^{\circ} \mathrm{C}$, except in the Amundsen and Bellingshausen Seas and the eastern Weddell Sea. The largest warming occurs at $216 \mathrm{~m}$ (Fig. $3 \mathrm{C}$ ), up to $1.2^{\circ} \mathrm{C}$. Large warming is also seen in the Atlantic and Pacific sectors of the ACC regions. Further down, the magnitude of warming tends to decrease but the warming area tends to increase. Below $\sim 1000 \mathrm{~m}$, almost all the Southern Ocean water south of $50^{\circ} \mathrm{S}$ is warmer with AISM (Fig. 3e and f). However, the magnitude of warming is spatially inhomogeneous. For example, at $1033 \mathrm{~m}$ (Fig. 3e), the largest $\Delta T$ is found in the Weddell Sea, up to $1.2^{\circ} \mathrm{C}$, and near the continent, generally $>0.6^{\circ} \mathrm{C}$. In other areas, warming is much smaller, generally $<0.4^{\circ} \mathrm{C}$. Down to the bottom, $\Delta T$ decreases. At the same time, the warming pattern also changes. At $3752 \mathrm{~m}$ (Fig. 3f), the largest warming $\left(>0.6^{\circ} \mathrm{C}\right)$ takes place in the AustraliaAntarctic Basin in the Indian Ocean, not next to the continent as in the shallower layers.

Figure 2 suggests that total AISM increased $\sim 10 \%$ between the mid-1960s (102 mSv) and the mid-1980s, after which it stayed fairly constant between 110 and $112 \mathrm{mSv}$. If the effect of AISM on Southern Ocean hydrography is correctly captured by the model, we should see similar trends in data although with much smaller total change.

Gille (2002) reported a warming of $0.17^{\circ} \mathrm{C}$ in the Southern Ocean waters at 700-1100m depth between the 1950s and 1980s. Most observed warming occurred in the ACC region between $45^{\circ} \mathrm{S}$ and $60^{\circ} \mathrm{S}$, especially in the Atlantic and Indian sectors. This is almost identical to the warming pattern shown above as a result of increasing AISM (Fig. 3d and e). Aoki and others (2003) showed another example at depths of $200-900 \mathrm{~m}$ around $30-150^{\circ} \mathrm{E}$ in the ACC region, where warming over three decades (1966-98) suggested that the southern ACC front had shifted southward. A similar warming is reproduced in our model (Fig. 3c-e). Levitus and others (2005) reported changes in ocean heat content vs time for 0-300, 0-700 and 0-3000 m integrations, finding that about half of the increased heat content was from the Atlantic Ocean. They also noted the cooling above $\sim 600 \mathrm{~m}$ and between 1100 and $1450 \mathrm{~m}$ at high southern latitudes. The cooling above $\sim 600 \mathrm{~m}$ is reproduced near the coastal regions (Fig. 3), whereas the cooling below $\sim 1100 \mathrm{~m}$ is not reproduced in our simulation. This is possibly caused by the dynamic responses of ISM to changing wind (Pritchard and others, 2012; Steig and others, 2012), or by the Antarctic Surface Water flushing and melting the ice base (Hattermann and others, 2012), which are not captured by the model.

The warming of the deep and bottom waters in the Southern Ocean over the past half-century has been reported by a number of studies. Fahrbach and others (1998) observed that the bottom water in the central Weddell Sea became warmer during the interval 1989-95. This warming trend was shown to affect most of the Weddell Sea when the data were extended to the early 2000s (Fahrbach and others, 2004). Observations dating back to 1912 indicated that the warming of the Weddell Sea Warm Deep Water had occurred since the 1970s (Robertson and others, 2002). The warming of the bottom water was also observed in the Indian sector (Whitworth, 2002; Johnson and others, 2008) and Pacific sector (Ozaki and others, 2009) of the Southern Ocean. In particular, Ozaki and others (2009) revealed a long-term warming of the bottom layer of the Ross Sea from 1969 to 2004. Johnson and others (2008) reported warming of the abyssal waters in the eastern Indian Ocean between 1994/95 and 2007. These warming trends are consistent with the effects of including AISM (Fig. 3e and f).

\subsection{Impact of AISM on salinity}

The impact of AISM on the Southern Ocean salinity at different levels is shown in Figure 4. AISM inputs fresh water into the adjacent ocean. As for temperature, the strongest freshening is seen close to $216 \mathrm{~m}$ (Fig. 4c), but with large and extensive freshening at shallower depths as well (Fig. 4a and b). At $216 \mathrm{~m}$, the largest freshening is in the vicinity of the continent (down to -1 ), where most of the ice-shelf/ocean interaction was applied in the model. In addition, freshening is dominant over the whole Southern Ocean at this depth, except for patches of slightly higher salinity (up to 0.1 ) in the central Kerguelen, Weddell and Ross gyres.

The substantial freshening at the surface (Fig. 4a and b) arises because the fresh subsurface water rises to the surface due to its low density. The freshening at the surface is particularly remarkable in the Ross and Weddell Seas (down to -0.5 ), the Amundsen and Bellingshausen Seas (down to -0.4) and Prydz Bay (down to -0.3). In the Indian Ocean and western Weddell Sea, the freshening is generally much weaker. In the region east of $45^{\circ} \mathrm{E}$, the water even becomes more saline, up to 0.2 . At $55 \mathrm{~m}$, almost all of the Southern Ocean becomes fresher (Fig. 4b). Unlike at the surface, the freshening is more pronounced next to the continent at this depth. Aside from the general freshening, small areas of more saline water up to 0.1 are found around the $45^{\circ} \mathrm{E}$ meridian and in the southern Ross Sea.

At depths of 512 and $1033 \mathrm{~m}$, inclusion of AISM generally causes higher salinity in the Southern Ocean (Fig. 4d and e). Freshening is only found in the Weddell and Ross Seas close to the continent, where the decrease in salinity is up to 0.3. At the bottom (Fig. 4f), most of the Southern Ocean south of $\sim 55^{\circ} \mathrm{S}$ shows a trend of reduced salinity when AISM is included, although the changes are small $(<0.02)$.

As with temperature (Section 3.2), we can use these model results to predict the change in the Southern Ocean salinity associated with the modeled $10 \%$ increase in AISM between the 1960s and 1980s (Fig. 2). Wong and others (1999) found a large-scale freshening of intermediate water in the Pacific and Indian Oceans between the periods 193080 and 1985-94, and partly attributed this to surface water freshening in the source region of the Southern Ocean. They 

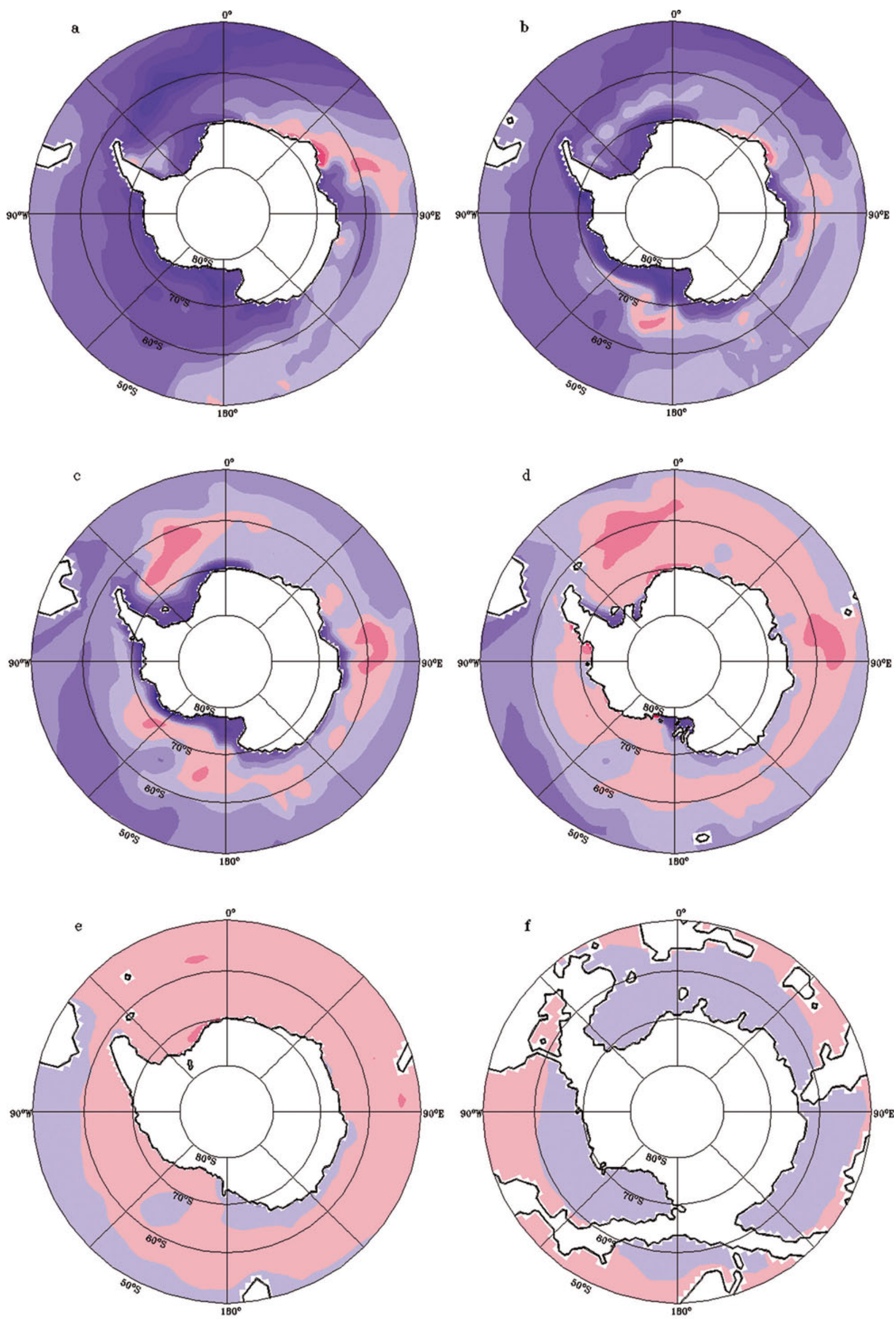

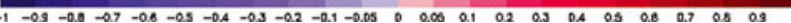

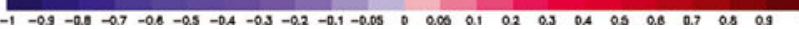

Fig. 4. Same as Figure 3, but for salinity. 
estimated a net increase in freshwater flux of $\sim 31 \mathrm{~mm} \mathrm{a}^{-1}$ $(\sim 22 \mathrm{mSv})$ for the Southern Ocean between $55^{\circ} \mathrm{S}$ and $65^{\circ} \mathrm{S}$. The increasing freshwater input is $8-12.5 \mathrm{~mm} \mathrm{a}^{-1}$ ( 6-9 mSv) from coupled atmosphere-ocean models, with increasing atmospheric greenhouse-gas concentration for the same period (Manabe and others, 1990; Gordon and O'Farrell, 1997), which could explain about one-third of the net increase in freshwater flux. The increase in the simulated freshwater flux from AISM between the mid-1960s and mid1980 s is $\sim 10 \mathrm{mSv}$ (Fig. 2). It is likely a significant contributor to the freshwater flux variability. In addition, the simulated large salinity decrease in the vicinity of ice shelves is not inconsistent with summer observations near the RIS by Jacobs and others (2002), who found a rapid freshening in the surface water in the Ross Gyre and much deeper close to the ice-shelf edge. Jacobs and others (2002) attributed this freshening to the increasing AISM in the Bellingshausen and Amundsen Seas, which is also found in later in situ observations (e.g. Shepherd and others, 2004; Wåhlin and others, in press).

The modeled spatial extent of surface freshening down to $500 \mathrm{~m}$ in the Pacific, Atlantic and Indian sectors is generally consistent with the observed freshening (Boyer and others, 2005). It is seen from the observations that strong freshening occurs in the Pacific and Atlantic sectors of the high-latitude Southern Ocean, with the most significant salinity decrease in the top surface waters. In the Indian sector of the Southern Ocean, however, the observed overall salinity is slightly increasing (Boyer and others, 2005). This pattern is qualitatively depicted in the present study (Fig. 4), where the freshening in the Indian sector is much weaker than in the Pacific and Atlantic sectors. Consistent with recent observations by Rintoul (2007), Johnson and others (2008) and Ozaki and others (2009), increasing AISM would cause freshening of the bottom water in the Southern Ocean (Fig. 4). Such overall consistency presented in this study has not been simulated in any previous study.

\subsection{Impact of AISM on density}

Potential density is determined by both temperature and salinity. However, in most regions of the cold Southern Ocean, density is mainly controlled by salinity. Therefore, the general patterns of density change (Fig. 5) are similar to those of salinity at most of the vertical levels, where density generally decreases. The largest decrease in density $(>0.2 \mathrm{~kg}$ $\mathrm{m}^{-3}$ ) is found at the surface (Fig. 5a), particularly in the Weddell, Bellingshausen, Amundsen and Ross seas. Below the surface layer, a large decrease in density is mainly confined to the continental margins down to $216 \mathrm{~m}$. At $1033 \mathrm{~m}$, the water decreases slightly in density in a fairly large area (Fig. 5e), where both temperature (Fig. 3e) and salinity (Fig. 4e) increase due to the inclusion of AISM. Here the increase in temperature plays a dominant role in the density change. At $3752 \mathrm{~m}$ the decrease is generally $<0.1 \mathrm{~kg} \mathrm{~m}^{-3}$.

The simulated density decrease in the bottom water is consistent with observations (Whitworth, 2002; Aoki and others, 2003; Rintoul, 2007; Johnson and others, 2008; Ozaki and others, 2009). Due to the rapid freshening of the bottom water, the decrease in density is also significant, resulting in loss of the densest water classes (e.g. Johnson and others, 2008). Additionally, warming of the intermediate water would also cause a decrease in density. Such changes may reduce the stability of the water column, enhancing eddy formation due to baroclinic instability (e.g. Meredith and Hogg, 2006; Screen and others, 2009).

\section{CONCLUSIONS}

We have investigated the effects of increasing AISM on Southern Ocean hydrography. Meltwater from AISM is mainly confined to the vicinity of the ice shelves. Due to its lower density, the freshened water rises, causing strong freshening and cooling of the upper-ocean Antarctic coastal waters. The freshened upper-ocean water is advected northward by wind stress, and is replaced by warmer and more saline deep water flowing southward towards the ice fronts.

Our model run with AISM suggests that the total circumpolar meltwater flux increased $\sim 10 \%$ from a minimum in the mid-1960s to a fairly stable maximum value from the mid-1980s (Fig. 2). Southern Ocean hydrographic changes reported in many studies (e.g. Wong and others, 1999; Levitus and others, 2000; Gille, 2002; Robertson and others, 2002; Aoki and others, 2003; Boyer and others, 2005; Jacobs, 2006; Rintoul, 2007; Ozaki and others, 2009) are qualitatively consistent with the modeled effect of increasing AISM. Ice-shelf melting tends to freshen the surface water, warm the intermediate and deep waters, and freshen and warm the bottom water in the Southern Ocean.

If we assume that the effect of increasing AISM is linear through the range of our two model runs, we can scale predicted hydrographic changes by $10 \%$ to estimate expected changes from the mid-1960s to the mid-1980s and later. For example, in the Weddell Sea the temperature difference at $1033 \mathrm{~m}$ between the simulations with and without AISM is $\sim 0.6^{\circ} \mathrm{C}$. This suggests that the actual warming caused by increasing AISM would be $\sim 0.06^{\circ} \mathrm{C}$ between 1965 and 2000, about one-third of the observed $0.17^{\circ} \mathrm{C}$ between 1950 and 1980 in the same area (Gille, 2002). This implies that increasing AISM is likely a significant contributor to recent changes in the Southern Ocean. However, due to the difficulty of exactly determining AISM and its circumpolar amount, as well as the sparsity of samples in the high-latitude Southern Ocean, more studies are needed to clarify their exact relations.

We have not investigated the detailed causes of the modeled changes in AISM between 1958 and 2000 (Fig. 2), although a likely factor is changes in hemispheric wind fields (Pritchard and others, 2012; Steig and others, 2012). Our results suggest that, if AISM increases for some reason, the wind-driven offshore transport of near-surface freshened water will be associated with southward transport of warmer intermediate layers, leading to further increases in AISM. That is, there is a positive feedback between AISM and hydrography that can increase the effect of climate perturbations on Antarctic ice-sheet mass balance. However, further studies are required to quantify other causes of hydrographic variability, including changes in winds and sea-ice production in, and export from, Antarctic coastal regions.

\section{ACKNOWLEDGEMENTS}

We thank the DRAKKAR group for providing the ORCA2-LIM configuration, especially Jean-Marc Molines for his assistance in setting up the model in Helsinki. We are grateful to Aike Beckmann and anonymous reviewers for constructive comments which substantially improved 

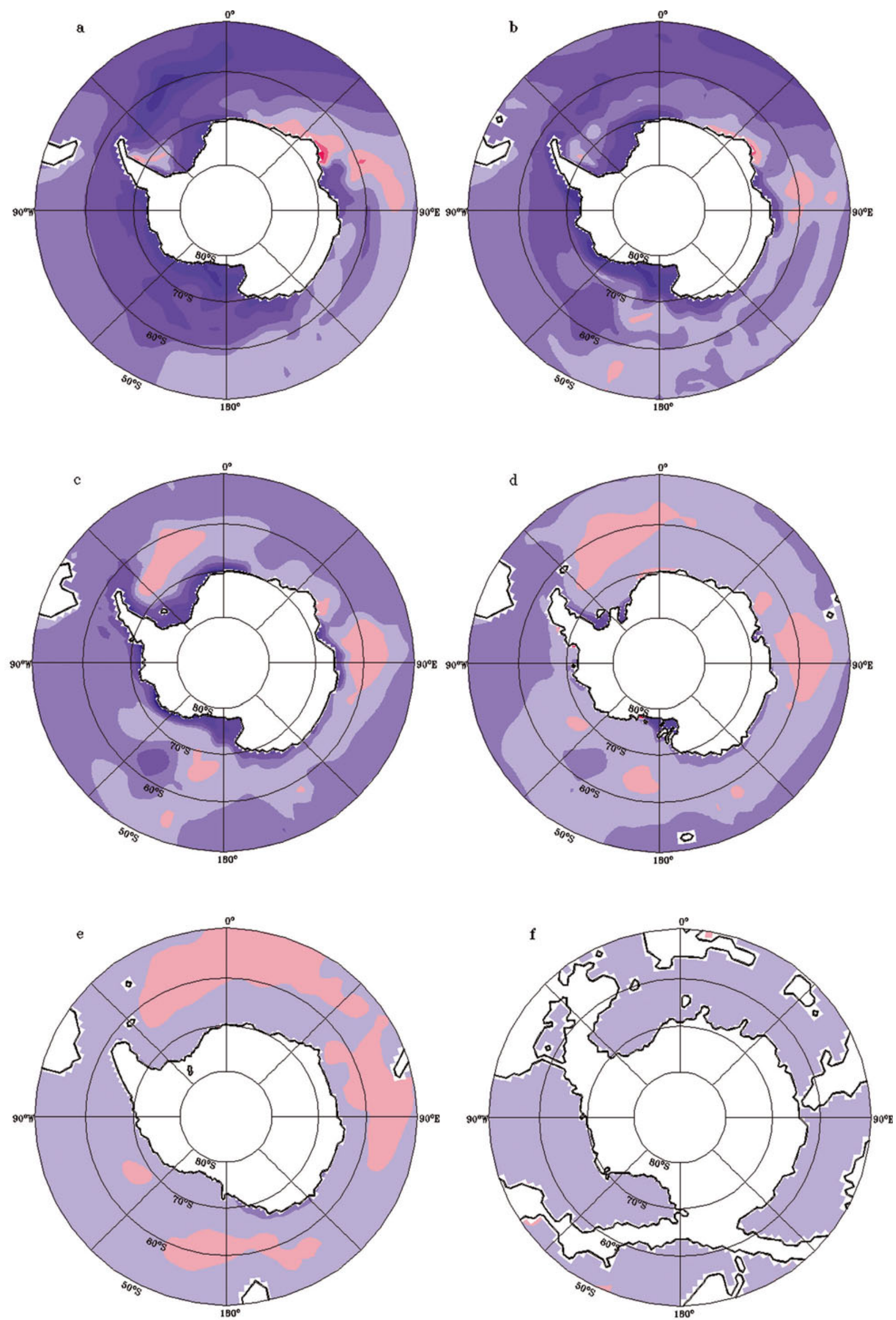

$\begin{array}{lllllllllllllllll}-0.7 & -0.6 & -0.5 & -0.4 & -0.3 & -0.2 & -0.1 & -0.05 & 0 & 0.05 & 0.1 & 0.2 & 0.3 & 0.4 & 0.5 & 0.6 & 0.7\end{array}$

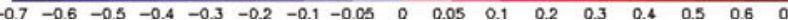

Fig. 5. Same as Figure 3, but for density $\left(\mathrm{kg} \mathrm{m}^{-3}\right)$. 
the manuscript. This study was supported by the University of Helsinki through the project EPOS. The simulations were carried out at the Finnish Center for Scientific Computing.

\section{REFERENCES}

Aoki S, Yoritaka M and Masuyama A (2003) Multidecadal warming of subsurface temperature in the Indian sector of the Southern Ocean. J. Geophys. Res., 108(C4), 8081 (doi: 10.1029/ 2000JC000307)

Beckmann A and Goosse H (2003) A parameterization of ice shelf-ocean interaction for climate models. Ocean Model., 5(2), 157-170 (doi: 10.1007/s10712-011-9123-5)

Beckmann A and Timmermann R (2001) Circumpolar influences on the Weddell Sea: indication of an Antarctic circumpolar coastal wave. J. Climate, 14(17), 3785-3792 (doi: 10.1175/15200442(2001)014<3785:CIOTWS>2.0.CO;2)

Beckmann A, Hellmer HH and Timmermann R (1999) A numerical model of the Weddell Sea: large-scale circulation and water mass distribution. J. Geophys. Res., 104(C10), 23 375-23 392 (doi: 10.1029/1999JC900194)

Boyer TP, Levitus S, Antonov Jl, Locarnini RA and Garcia HE (2005) Linear trends in salinity for the World Ocean, 19551998. Geophys. Res. Lett., 32(1), L01604 (doi: 10.1029/ 2004GL021791)

Drewry DJ (1983) Antarctica: glaciological and geophysical folio. Scott Polar Research Institute, Cambridge

Fahrbach E, Meyer R, Rohardt G, Schröder M and Woodgate RA (1998) Gradual warming of the Weddell Sea deep and bottom water. FRISP Rep. 12, 24-34 (hdl:10013/epic.18699)

Fahrbach E, Hoppema M, Rohardt G, Schröder M and Wisotzki A (2004) Decadal-scale variations of water mass properties in the deep Weddell Sea. Ocean Dyn., 54(1), 77-91 (doi: 10.1007/ s10236-003-0082-3)

Fichefet T and Morales Maqueda MA (1997) Sensitivity of a global sea ice model to the treatment of ice thermodynamics and dynamics. J. Geophys. Res., 102(C6), 12609-12646 (doi: 10.1029/97JC00480)

Gille ST (2002) Warming of the Southern Ocean since the 1950s. Science, 295(5558), 1275-1277 (doi: 10.1126/science.1065863)

Gille ST (2003) Float observations of the Southern Ocean. Part I: estimating mean fields, bottom velocities, and topographic steering. J. Phys. Oceanogr., 33(6), 1167-1181 (doi: 10.1175/ 1520-0485(2003)033<1167:FOOTSO>2.0.CO;2)

Gordon HB and O'Farrell SP (1997) Transient climate change in the CSIRO coupled model with dynamic sea ice. Mon. Weather Rev., 125(5), 875-907 (doi: 10.1175/1520-0493(1997)125 $<0875$ :TCCITC>2.0.CO;2)

Hattermann T, Nøst OA, Lilly JM and Smedsrud LH (2012) Two years of oceanic observations below the Fimbul Ice Shelf, Antarctica. Geophys. Res. Lett., 39(12), L12605 (doi: 10.1029/ 2012GL051012)

Hellmer HH (2004) Impact of Antarctic ice shelf basal melting on sea ice and deep ocean properties. Geophys. Res. Lett., 31(10), L10307 (doi: 10.1029/2004GL019506)

Hibler WD, III (1979) A dynamic thermodynamic sea ice model. J. Phys. Oceanogr., 9(7), 815-846

Holland PR, Jenkins A and Holland DM (2010) Ice and ocean processes in the Bellingshausen Sea, Antarctica. J. Geophys. Res., 115(C5), C05020 (doi: 10.1029/2008JC005219)

Jacobs S (2006) Observations of change in the Southern Ocean. Philos. Trans. R. Soc. London, Ser. A, 364(1844), 1657-1681 (doi: 10.1098/rsta.2006.1794)

Jacobs SS, Hellmer HH, Doake CSM, Jenkins A and Frolich RM (1992) Melting of ice shelves and the mass balance of Antarctica. J. Glaciol., 38(130), 375-387

Jacobs SS, Hellmer HH and Jenkins A (1996) Antarctic ice sheet melting in the southeast Pacific. Geophys. Res. Lett., 23(9), 957-960 (doi: 10.1029/96GL00723)
Jacobs SS, Giulivi CF and Mele PA (2002) Freshening of the Ross Sea during the late 20th century. Science, 297(5580), 386-389 (doi: 10.1126/science.1069574)

Jacobs SS, Jenkins A, Giulivi CF and Dutrieux P (2011) Stronger ocean circulation and increased melting under Pine Island Glacier ice shelf. Nature Geosci., 4(8), 519-523 (doi: 10.1038/ngeo1188)

Jenkins $A$ and Jacobs S (2008) Circulation and melting beneath George VI Ice Shelf, Antarctica. J. Geophys. Res., 113(C4), C04013 (doi: 10.1029/2007JC004449)

Johnson GC, Purkey SG and Bullister JL (2008) Warming and freshening in the abyssal southeastern Indian Ocean. J. Climate, 21(20), 5351-5363 (doi: 10.1175/2008JCLI2384.1)

Levitus S, Antonov JI, Boyer TP and Stephens C (2000) Warming of the world ocean. Science, 287(5461), 2225-2229 (doi: 10.1126/ science.287.5461.2225)

Levitus S, Antonov JI and Boyer TP (2005) Warming of the world ocean, 1955-2003. Geophys. Res. Lett., 32(2), L02604 (doi: 10.1029/2004GL021592)

Madec G, Delecluse P, Imbard M and Lévy C (1998) OPA 8.1 Ocean General Circulation Model reference manual. Institut PierreSimon Laplace (IPSL), Paris (Note du Pole de modélisation 11)

Manabe S, Bryan K and Spelman MJ (1990) Transient response of a global ocean-atmosphere model to a doubling of atmospheric carbon dioxide. J. Phys. Oceanogr., 20(5), 722-749 (doi: 10.1175/1520-0485(1990)020<0722:TROAGO>2.0.CO;2)

Meredith MP and Hogg AM (2006) Circumpolar response of Southern Ocean eddy activity to a change in the Southern Annular Mode. Geophys. Res. Lett., 33(16), L16608 (doi: 10.1029/2006GL026499)

Ozaki H, Obata H, Naganobu M and Gamo T (2009) Long-term bottom water warming in the north Ross Sea. J. Oceanogr., 65(2), 235-244 (doi: 10.1007/s10872-009-0022-z)

Payne AJ, Holland PR, Shepherd AP, Rutt IC, Jenkins A and Joughin I (2007) Numerical modeling of ocean-ice interactions under Pine Island Bay's ice shelf. J. Geophys. Res., 112(C10), C10019 (doi: 10.1029/2006JC003733)

Pritchard HD, Ligtenberg SRM, Fricker HA, Vaughan DG, Van den Broeke MR and Padman L (2012) Antarctic ice-sheet loss driven by basal melting of ice shelves. Nature, 484(7395), 502-505 (doi: 10.1038/nature10968)

Rignot EJ (1998) Fast recession of a West Antarctic glacier. Science, 281(5376), 549-551 (doi: 10.1126/science.281.5376.549)

Rignot E and Jacobs SS (2002) Rapid bottom melting widespread near Antarctic ice sheet grounding lines. Science, 296(5575), 2020-2023 (doi: 10.1126/science.1070942)

Rintoul SR (2007) Rapid freshening of Antarctic Bottom Water formed in the Indian and Pacific oceans. Geophys. Res. Lett., 34(6), L06606 (doi: 10.1029/2006GL028550)

Robertson R, Visbeck M, Gordon AL and Fahrbach E (2002) Longterm temperature trends in the deep waters of the Weddell Sea. Deep-Sea Res. II, 49(21), 4791-4806 (doi: 10.1016/S09670645(02)00159-5)

Schodlok M, Menemenlis D, Rignot E and Studinger M (2012) Sensitivity of the ice-shelf/ocean system to the sub-ice-shelf cavity shape measured by NASA IceBridge in Pine Island Glacier, West Antarctica. Ann. Glaciol., 53(60 Pt 2), 156-162 (doi: 10.3189/2012AoG60A073)

Screen JA, Gillett NP, Stevens DP, Marshall GJ and Roscoe HK (2009) The role of eddies in the Southern Ocean temperature response to the southern annular mode. J. Climate, 22(3), 806-818 (doi: 10.1175/2008JCLI2416.1)

Semtner AJ, Jr (1976) A model for the thermodynamic growth of sea ice in numerical investigations of climate. J. Phys. Oceanogr., 6(5), 379-389 (doi: 10.1175/1520-0485(1976)006<0379: AMFTTG $>2.0 . \mathrm{CO} ; 2$ )

Shepherd A, Wingham D and Rignot E (2004) Warm ocean is eroding West Antarctic Ice Sheet. Geophys. Res. Lett., 31(23), L23404 (doi: 10.1029/2004GL021106)

Steig EJ, Ding Q, Battisti DS and Jenkins A (2012) Tropical forcing of Circumpolar Deep Water Inflow and outlet glacier thinning in 
the Amundsen Sea Embayment, West Antarctica. Ann. Glaciol., 53(60 Pt 1), 19-28 (doi: 10.3189/2012AoG60A110)

Thoma M, Grosfeld K and Lange MA (2006) Impact of the Eastern Weddell Ice Shelves on water masses in the eastern Weddell Sea. J. Geophys. Res., 111(C12), C12010 (doi: 10.1029/ 2005JC003212)

Thoma M, Jenkins A, Holland D and Jacobs S (2008) Modelling circumpolar deep water intrusions on the Amundsen Sea continental shelf, Antarctica. Geophys. Res. Lett., 35(18), L18602 (doi: 10.1029/2008GL034939)

Timmermann R, Hellmer HH and Beckmann A (2002) Simulations of ice-ocean dynamics in the Weddell Sea 2. Interannual variability 1985-1993. J. Geophys. Res., 107(C3), 3025 (doi: 10.1029/2000JC000742)

Timmermann R, Goosse H, Madec G, Fichefet T, Ethe C and Dulière V (2005) On the representation of high latitude processes in the ORCA-LIM global coupled sea ice-ocean model. Ocean Model., 8(1-2), 175-201 (doi: 10.1016/j.ocemod.2003.12.009)

Wåhlin AK, Yuan X, Björk G and Nohr C (2010) Inflow of warm circumpolar deep water in the Central Amundsen Shelf. J. Phys. Oceanogr., 40(6), 1427-1434 (doi: 10.1175/2010JPO4431.1)
Wåhlin A and 6 others (in press) Some implications of Ekman layer dynamics for cross shelf exchange in the Amundsen Sea. J. Phys. Oceanogr. (doi: 10.1175/JPO-D-11-041.1)

Walkden GJ, Heywood KJ, Nicholls KW and Abrahamsen P (2009) Freshwater transport at Fimbulisen, Antarctica. J. Geophys. Res., 114(C8), C08014 (doi: 10.1029/2008JC005028)

Walker DP, Brandon MA, Jenkins A, Allen JT, Dowdeswell JA and Evans J (2007) Oceanic heat transport onto the Amundsen Sea shelf through a submarine glacial trough. Geophys. Res. Lett., 34(2), L02602 (doi: 10.1029/2006GL028154)

Wang C (2011) Antarctic ice shelf melting and its impact on the global sea ice-ocean system. Rep. Ser. Geophys. 67

Wang C and Beckmann A (2007) Investigation of the impact of Antarctic ice-shelf melting in a global ice-ocean model (ORCA2-LIM). Ann. Glaciol., 46, 78-82 (doi: 10.3189/ $172756407782871602)$

Whitworth TI (2002) Two modes of bottom water in the AustralianAntarctic Basin. Geophys. Res. Lett., 29(5), 1073 (doi: 10.1029/ 2001GL014282)

Wong APS, Bindoff NL and Church JA (1999) Large-scale freshening of intermediate waters in the Pacific and Indian oceans. Nature, 400(6743), 440-443 (doi: 10.1038/22733)

MS received 17 January 2012 and accepted in revised form 6 September 2012 